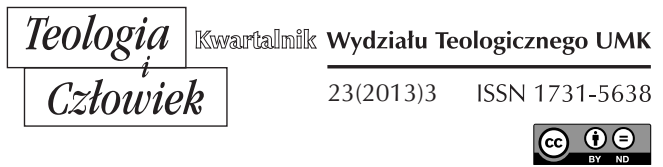

KS. KRZYSZTOF GÓŹDŹ*

LUBLIN

\title{
WIARA W ROZUMIENIU JOSEPHA RATZINGERA - BENEDYKTA XVI
}

DOI: http://dx.doi.org/10.12775/TiCz.2013.036

Data 12 września 2006 roku wpisuje się na stałe do kalendarza pontyfikatu Benedykta XVI. Przebywał on wtedy - podczas zagranicznej pielgrzymki do swojej ojczyzny - w Ratyzbonie, gdzie wygłosił wykład do przedstawicieli nauki pod tytułem „Wiara, rozum i uniwersytet”. Serce tej lectio stanowiła relacja wiary i rozumu. Ratzinger jako profesor tego uniwersytetu przypomniał sytuację sprzed wielu lat, kiedy to jeden z jego kolegów powiedział, że na „uniwersytecie występuje dziwne zjawisko: dwa fakultety zajmują się czymś, co nie istnieje - czyli Bogie$\mathrm{m}^{\prime \prime}$. I zapewne na tym spostrzeżeniu zasadza się sedno tzw. Wykładu Ratyzbońskiego: między wiarą a rozumem istnieje istotna więź - wiara ma swoje uzasadnienie i nie można wierzyć wbrew rozumowi. Podczas gdy światowe media zwrócily uwagę na jedno tylko zdanie cytowane za badaniami prof. Theodera Kohury'ego w rozmowie między cesarzem Manuelem II Paleologiem a wykształconym Persem: „Pokaż mi, co przy-

“ Ks. prof. dr hab. Krzysztof Góźdź - kierownik Katedry Dogmatów na Wydziale Teologii Katolickiego Uniwersytetu Lubelskiego Jana Pawła II w Lublinie.

${ }^{1}$ P. Rodari, A. Tornielli, Atak na Ratzingera, Częstochowa 2011, s. 17 (za „L'Osservatore Romano", wyd. polskie 2006/11). 
niósł Mahomet, co byłoby nowe, a odkryjesz tylko rzeczy złe i nieludzkie, takie jak nakaz zaprowadzania mieczem wiary, którą głosił", to Papież chciał wyrazić opinię samego cesarza, który tłumaczył powody, że nierozumnym jest rozpowszechnianie wiary przemocą. I powiedział, że wiara rodzi się z duszy, a nie z ciała. Ważne jest rozumowanie duszy, a nie przemoc ciała. Dlatego wszelkie działanie, które jest niezgodne z działaniem duszy, czyli rozumem - jest sprzeczne z naturą Bożą. Oznacza to, że rozum nie może być postrzegany jako przeszkoda do wiary, wprost przeciwnie.

Wychodzi tu Anzelmowe fides quaerens intellectum - wiara pyta rozumu, wiara szuka zrozumienia. Anzelm z Canterbury uważał, że wiara jest darem łaski, ale człowiek wierzący szuka zrozumienia wiary i treści wiary. Jako przykład niech posłuży zdanie "Chrystus jest Bogiem". Tę prawdę znam tylko z wiary. Ale kiedy chcę tę prawdę przyjąć, to staram się przeniknąć ją rozumem. Wtedy ta prawda - choć do końca nie poznam jej rozumem - nie jest irracjonalna. Dzięki tej akcji rozumowej można związać poszczególne prawdy ze sobą i tworzyć racjonalną teologię. Dzisiaj uważamy, że przyjęcie łaski wiary jest jednak dziełem rozumu i woli, a więc współpracy z łaską Bożą, a nie tylko dziełem samego Boga. Przyjęcie wiary jest więc współpracą rozumu z łaską. W tym Ratzinger uzupełnił Anzelma.

Na tym właśnie aksjomacie współpracy rozumu z łaską Bożą Ratzinger buduje swoje rozumienie wiary, uzupełniając je jeszcze własną chrystologią Logosu². Logos nie jest już tylko „sensem”, „myślą" istniejącą poza rzeczami, ale On sam wszedł w ciało i ucieleśnił się, jest Logos incarnatus. Dlatego wiara w ten Logos jest konieczna dla człowieka, aby mógł otrzymać nowe, wieczne życie w Bogu, a przez to starał się już teraz przemienić obecny świat $w$ Boży świat. Zatem wiara nie jest żadną ślepą teorią, jakąś przestarzałą ideą, ani też jakąś zagmatwaną filozofią, lecz jest „znajdowaniem drogi do mądrości, rozumności, rzeczowości, dostrzegania pełnej rzeczywistości" ${ }^{\prime \prime}$. Taka wiara staje się prawdziwą bramą do komunii z Bogiem, Panem historii i Panem naszego świata. Zatem wiara jest kategorią osobową, a nie reistyczną. Dotyczy relacji

${ }^{2}$ K. Góźdź, Logos-Christologie nach Joseph Ratzinger, w: Logos et musica. In honorem Summi Romani Pontificis Benedicti XVI, Frankfurt a. M. 2012, s. 153-162.

${ }^{3}$ J. Ratzinger, Opera Omnia, t. 12: Gtosiciele Stowa i studzy Waszej radości, Lublin 2012, s. 459; por. K. Góźdź, Relaność i racjonalność wiary chrześcijańskiej, w: A. Kiciński, P.T. Goliszek (red.), Cathechetica Porta Fidei, Lublin 2012, s. 13-21. 
osobowych, a nie rzeczowych. Jest żywą relacją między człowiekiem a Bogiem, między osobą człowieka, stworzonego na obraz Boży, a Bogiem w Trójcy Osób. Jest to wreszcie relacja osobowej miłości, gdyż Bóg jest Miłością (1 J 4,8), która udziela się człowiekowi. „Wiara jest więc decyzją na to, żeby być z Panem, aby z Nim żyć"4. Decyzja ta nie może być jednak ślepa, lecz winna opierać się na Logosie, by w ten sposób być także realną rzeczywistością.

Teologia klasyczna rozróżniała: wiarę, którą się wierzy - fides qua creditur oraz wiarę jako zespół prawd objawionych, prawdy wiary, treści nauki - fides quae (lub quod) creditur. Z góry należy powiedzieć, że Ratzingerowe ujęcie wiary (fides qua) charakteryzują trzy zasadnicze aspekty: jest to fenomen osobowy (1), wiąże się z Chrystusem jako Logosem Słowem i Sensem (2) i jest najwyższą realnością człowieczą w Bogu (3).

W krótkim wykładzie pójdźmy więc śladem wyznaczonym przez samego Josepha Ratzingera, który określa wiarę jako: mądrość, rozumność i realność.

\section{WIARA JAKO MĄDROŚĆ}

Mądrość wiary to najsłuszniejsze odniesienie świata historii, ludzi i siebie samego, moich wszystkich działań do najwyższego Celu, Sensu, Finału i Pleromy rzeczywistości. Wiara, którą wierzymy (fides qua), nie jest rzeczą, zwykłą funkcją, aktem, czymś przypadkowym dla człowieka lub czymś izolowanym od jego bytu i od stworzenia w ogóle, lecz jest najmocniejszym przylgnięciem całoosobowym człowieka do Chrystusa jako Osoby, jako Logosu, czyli Słowa Bożego, Sensu i Rozumu w rzeczywistości stworzonej - przylgnięciem naszym ,ja”, naszym całym umysłem, intelektem, wolą, uczuciem, czynem, twórczością i wyższą transformacją siebie i całego stworzenia Bożego (por. Rz 8,18-24). Ratzinger - Benedykt XVI przyjmuje w swej teologii, jak sam mówi, personalizm, zapewne augustyński ${ }^{5}$. I stąd ujmuje wszelką rzeczywistość: Boga, człowieka, świat, dzieje, Kościół, zbawienie z punktu osoby jako najwyższego bytu i najgłębszego sensu wszelkiej rzeczywistości. Inaczej mówiąc, Osoby Boże i osoba ludzka - w sposób dalekiej analogii - są

${ }^{4}$ Porta fidei, $10,3$.

${ }^{5}$ Por. Joseph Ratzinger Gesammelte Schriften, t. 1: Volk und Haus Gottes in Augustinus Lehre von der Kirche, Freiburg im Breisgau 2011. 
najwyższą i absolutną racją istnienia Boga i człowieka. Stąd wiara to nie tylko jakaś myśl o Bogu, jakąś ufność, czy gest ofiarny, lecz także nowy rodzaj egzystencji człowieka jako osoby w Osobach Bożych - realnie, ponadrealnie, spełnieniowo, pleromicznie. Jest to wwiązanie osoby ludzkiej w Osoby Boże (Inpersonlisation) ${ }^{6}$.

Dlatego według Ratzingera - Benedykta XVI popularne, nawet wśród teologów, powiedzenie, że „wiara jest łaską”, nie oddaje pełnej prawdy o wierze i może być rozumiane nawet błędnie. Zdarza się często, że różni ludzie, najczęściej niewierzący, wygłaszają niby teologiczne teorie, że „nie otrzymali łaski wiary”. Tym samym niejako obwiniaja samego Pana Boga, że im tej łaski jakoby nie dał i dlatego nie wierzą w Niego. W teologii są tu dwa stanowiska7: według jednych „wiara jest tylko łaską", zgodnie z banezjańską koncepcją łaski jako praemotio physica, czyli jakby fizycznej przemocy (co można odnieść najwyżej np. do nawrócenia św. Pawła Apostoła), a według drugich jest możliwa inicjacja wiary naturalnej: fides naturaliter acquisita, którą Bóg jednocześnie wspiera łaską. Otóż według Ratzingera - Benedykta XVI wiara jest misteryjną syntezą Boga i człowieka. Bóg daje łaskę wiary każdemu, ale w sensie skutecznym temu, kto się na nią zgodzi. Inaczej za niewiarę człowieka odpowiadałby Bóg, a sam człowiek byłby „wolny”.

Mówiąc inaczej, Bóg daje łaskę wiary, daje sam siebie każdemu człowiekowi i to zawsze, ale człowiek nie jest rzecza, istotą bezoosobowa, i dlatego narzucenie mu łaski „siłą” byłoby jego poniżeniem; stąd człowiek ma swój udział w zjawisku wiary, może się na nią otworzyć lub nie otworzyć, może ją przyjąć albo odrzucić, może ją rozżarzać a może ją zamącić - z powodu grzechów lub różnych innych przyczyn. Toteż wiara jest współkomunią osobową dwu lub więcej osób, a przede wszystkim osoby ludzkiej z Osobą Bożą na sposób osobowy, nie reistyczny. I tak wiara ma charakter ontyczny i realistyczny: jest realnym związkiem osobowym bytu ludzkiego z Bytem Bożym. I człowiek może ją dopełnić we współpracy z Chrystusem i Duchem Świętym, żeby stać się Bożym człowiekiem.

${ }^{6}$ Por. K. Góźdź, Die personalelistische Ergänzung des Chalkedonischen Dogmas, w: Ch. Schaller, M. Schulz, R. Voderholzer (red.), Mittler und Bereier. Die christologische Dimension der Theologie, Freiburg i. Br. 2008, s. 109.

${ }^{7}$ Por. nowe ujęcie traktatu o łasce hiszpańskiego teologa: J. L. Lorda, Łaska Boża, tł. J. Lekan, Lublin 2012. 
Mądrościowy, a zarazem osobowy charakter wiary dostrzegał Ratzinger już w latach 60. XX wieku. Według niego istota chrześcijaństwa wyraża się głównie w tym, że jest ono „wiarą" w Jezusa Chrystusa jako wcielonego Syna Bożego. Wiara ta nie jest jednak "ujrzeniem” czy wręcz "dotknięciem", jak to zwykle bywa z osobą czy rzeczą w świecie widzialnym. Do wiary wiedzie inna droga. Jest nią "opowiedzenie się" za tym, czego nie można ani ujrzeć ani dotknąć. Opowiedzieć się za Jezusem jako Logosem oznacza konkretnie „ujrzeć" tę rzeczywistość jako tę, która „utrzymuje i umożliwia wszelką rzeczywistość”, a więc umożliwia także i moją ludzką egzystencję, umożliwia moje bycie człowiekiem, moje bytowanie na sposób ludzki. „Wierzyć znaczy uznać, że wewnątrz egzystencji ludzkiej istnieje punkt, który nie może zasilać się tym, co widoczne i dotykalne, ani na tym się opierać, ale który styka się z tym, czego dojrzeć nie można, tak że staje się to dla niego dotykalne i okazuje się niezbędne dla jego egzystencji"8. Taką postawę można osiągnąć jedynie przez proces, który Biblia określa jako „odwrócenie”, „nawrócenie”. Człowiek musi się "odwrócić” od tego, co widzialne, aby pójść za tym, co niewidzialne. Musi dokonać tego zwrotu swojej egzystencji.

Mądrość wiary polega więc na dwóch aspektach tego samego aktu: najpierw „stać przy czymś”, a następnie „rozumieć”. Wiara jako „stać" przy Bogu, oznacza trwać przy Nim. Jest to treść wiary, czyli ufne stanięcie na gruncie słowa Bożego, a więc zajęcie pewnego stanowiska. Natomiast „rozumieć" jest intelektualnym ujęciem wiary, które Septuaginta wyraża w słowach tradycji logosowej: "Jeśli nie uwierzycie, to i nie zrozumiecie" . Mamy tu do czynienia nie tylko z przyjmowaniem wiary od kogoś, ale też jej własnym rozumieniem. Do istoty wiary należy więc zawierzenie komuś, a nie sobie. Zawierzenie Temu, kto jest fundamentem mojego działania9. Wierzyć to zaufać Sensowi, który utrzymuje mnie jako człowieka i cały świat. Zatem moje istnienie jest odpowiedzią na Słowo-Logos, które wszystko podtrzymuje. Odpowiedź ta jest zgodą człowieka na sens, który może on jedynie otrzymać, a nie nadać. I dlatego wiara jest przyjęciem i powierzeniem się temu Sensowi ${ }^{10}$. Jest przyjęciem tego, co niewidzialne, przyjęciem tej rzeczywistości, której się człowiek powierza, i na której się opiera. Jedynie ta rzeczywistość, która jednocześnie jest osobowa i transcendentna, a więc jedynie ona jest Absolutem, i jako taka

\footnotetext{
${ }^{8}$ J. Ratzinger, Wprowadzenie w chrześcijaństwo, Kraków 1994, s. 43.

9 Tamże, s. 60.

${ }^{10}$ Tamże, s. 63.
} 
jest absolutnie Osobowa, a przez to jest źródłem i miejscem wszystkiego co duchowe, ma prawo odbierać pełną cześć naszej wiary ${ }^{11}$.

\section{WIARA JAKO ROZUMNOŚĆ}

Łacińskie słowo credo i hebrajskie amen, otwierające i zamykające wyznanie wiary, mają ten sam źródłosłów, oznaczający: stanąć z pełnym zaufaniem na konkretnej podstawie, której nie ja jestem twórcą, lecz Sens świata. Dlatego powierzam się temu Sensowi, a przez to przybliżam się do samej prawdy w nim tkwiącej, która się przede mną coraz bardziej otwiera. Wtedy wiara - rozumiana jako: zaufanie, zawierzenie, wierność, stałość, trwanie - oznacza ostateczne oparcie się na tej podstawie, która stanowi dla człowieka sens życia. Podstawą tą jest prawda, która pochodzi od sensu, od logosu. Dlatego wiara nie jest wiedzą o funkcjonalności, którą da się wyliczyć, lecz jest rozumieniem sensu, który się nam powierzył. Stąd wiara musi trwać przy tym sensie, trzymać się go, bo on jest jej oparciem ${ }^{12}$. Zatem „rozumienie wyrasta tylko z wiary. [...] Wiara i rozumienie należą do siebie nie mniej niż wiara i stanie przy czymś, bo stanie przy czymś i rozumienie są nierozłączne" ${ }^{\prime 13}$. W tym znaczeniu mówimy o misterium, które nie neguje rozumu, lecz umożliwia wiarę jako rozumienie. Ta rozumująca wiara trzyma się logosu, by mówić o Bogu jako tajemnicy, która nas ciągle uprzedza i pod każdym względem przekracza. Wiara ta ostatecznie wyraża się w osobowym wyznaniu: „Wierzę w Ciebie, Jezusa z Nazaretu, jako Sens (Logos) świata i mojego życia"14.

To wyznanie wiary w Jezusa rozbudowuje J. Ratzinger, mówiąc: „My natomiast mamy inną miarę wielkości: Syna Bożego, prawdziwego człowieka. To On jest wyznacznikiem prawdziwego humanizmu. Wiara «dorosła» nie idzie z prądem mód i nowinek; wiara dorosła i dojrzała jest głęboko zakorzeniona w przyjaźń z Chrystusem. Ta przyjaźń otwiera nas na każde dobro, dając nam zarazem kryterium rozeznania prawdy

11 Por. H. de Lubac, Das Apostolische Glaubensbekenntnis, w: J. Ratzinger, P. Henrici (red.), Credo. Ein theologisches Lesebuch, Köln 1992, s. 15.

${ }^{12}$ J. Ratzinger, Wprowadzenie w chrześcijaństwo, s. 67.

${ }^{13}$ Tamże, s. 68.

${ }^{14}$ Tamże, s. 70. 
i fałszu, odróżnienia ziarna od plew"15. Mocne stanowisko Kardynała określa jednoznacznie wiarę chrześcijańską. Posiada ona wymiar racjonalny, "logosowy" oraz egzystencjalny ${ }^{16}$. Następnie dodaje do tego jeszcze wymiar chrystologiczny i eklezjalny czyli wspólnotowy naszej wiary. „Wiara to głębokie przekonanie, że Bóg przez Chrystusa w Duchu Świętym rzeczywiście jest i działa w Kościele. Wierzyć znaczy być przekonanym, że Bóg jest wystarczająco duży, aby dostrzec także to, co małe, że On rzeczywiście może działać w świecie i że tam działa. Jest to przekonanie o tym, że On, ponieważ istnieje i ponieważ przed Nim znajduje się nasze życie, jest w tym naszym życiu najważniejszy. Dopiero tam, gdzie to przekonanie kształtuje postać życia, tam wiara jest pełna"17. Wiara rozświeca umysł, a rozum przyjmuje wiarę za swoją, za osobistą, za własną strukturę i człowiek wierzący jest w pełni rozumny. Przy tym wiara jest przyjmowana przez wolność rozumną i rozum wolny. Wiara jest rozumna dla człowieka, bo jest wolna (certitudo voluntaria), daje mu wolność, a nie niweczy go, nie gwałci ${ }^{18}$.

Dzięki rozumności wiara staje się światłem odkrywającym sens naszego życia, który płynie z poznania woli Bożej. „To coś pięknego - pisze Ratzinger - znać Boga i być poznanym przez Niego. To coś pięknego wiedzieć, jak On wygląda: w obliczu Chrystusa, który ukochał każdego z nas z osobna i za nas wydał się na śmierć, widzimy twarz samego Boga"19. Wartość naszej wiary winniśmy postrzegać od wewnątrz, od wypływającej z nas radości jaka jaśniała na twarzach pierwszych chrześcijan. Dopiero wtedy dostrzeżemy jak nieocenioną wartość posiada nasza wiara. Dopiero wtedy poznamy, że "ćwiczenie się w wierze jest ćwiczeniem się w prawdziwym człowieczeństwie oraz nauczeniem się rozumu wiary"20. W tym świetle jest w pełni zrozumiałe, że dzisiejszy człowiek potrzebuje odkryć na nowo Boga, ale nie jakiegoś tam boga, lecz Boga z ludzkim obliczem. Tym obliczem jest Jezus Chrystus.

${ }^{15}$ J. Ratzinger, Homilia na rozpoczęcie konklawe, z dnia 18 kwietnia 2005, w: Benedykt XVI, U progu pontyfikatu, Kraków 2005, s. 43.

${ }_{16}$ Por. M. Bartosiak, Wiara wedtug kard. Josepha Ratzingera, Łomża 2005, s. 10, 12.

17 JROO, t. 12, s. 297.

${ }_{18}$ Por. J. Ratzinger, Wiara i teologia (Wykład na Papieskim Wydziale Teologicznym we Wrocławiu z okazji nadania godności doktora honorowego), „Wrocławski Przegląd Teologiczny" R. 8, nr 2 (2000), s. 7-13.

${ }^{19}$ JROO, t. 12 , s. 325.

${ }^{20} \mathrm{JROO}$, t. 12, s. 48. 


\section{WIARA JAKO REALNOŚĆ}

Jeśli świat, rzeczywistość jest słowem Boga do człowieka, to Chrystus jest Sensem tego słowa i Duch Święty daje realne ujmowanie tego Sensu, a człowiek jako słowo stworzone może osiągnąć ten Sens - Logos Boży. Potrzebna jest mu do tego wiara, by spotkał Chrystusa, najpełniejszego świadka Boga Ojca, który przez swoje odwieczne zjednoczenie z Nim i "dzielenie” z nami Człowieczeństwa (Człowieczeństwo Boga) - jest obecnością Wiecznego na tym świecie. Dzięki temu wieczne staje się historyczne, niedotykalne daje się dotknąć, dalekie staje się bliskie, po prostu moje. W życiu Chrystusa, „W Jego bezwzględnym oddaniu swego istnienia ludziom mieści się sens świata: On nam oddaje się jako miłość, która także i mnie kocha i przez ten niepojęty dar trwałej miłości, której nie grozi żadna przemijalność, żadne zakłócenie egoizmem, czyni życie wartym życia"21.

Wiara chrześcijańska ma zatem swoją realność poprzez to, że jest wiarą trynitarną: wiarą w Ojca, w Logos i Pneumę̨2, uformowaną $\mathrm{w}$ tradycji apostolskiej i powiązaną z jednym podmiotem, którym jest Kościót. ${ }^{23}$ Wiara ta bazuje na fundamencie świętych wydarzeń Wcielenia, Krzyża i Zmartwychwstania ${ }^{24}$, rodzi się ze słuchania słowa Bożego, ${ }^{25}$ realizuje się w kulcie i liturgii Kościoła, ukierunkowana jest na Logos, stwórczy Rozum, który w Jezusie Chrystusie przyjął ciało ${ }^{26}$. Dlatego wiara ta, będąc wiarą we Wcielonego, jest wyznaniem wiary w Boga i staje się rzeczywista, pełna i jednocząca, gdy „On sam jest ciałem, gdy jest wydarzeniem sakramentalnym, w którym cielesny Pan przyjmuje naszą cielesną egzystencję ${ }^{27}$. Przez tę Ofiarę eucharystyczną dokonuje się głębokie przeobrażenie naszego bytu w Logosie i zjednoczenie z Nim. Tak kult sprawia, że sami upodabniamy się do $\operatorname{Logosu}^{28}$, realizujemy

${ }^{21}$ J. Ratzinger, Wprowadzenie w chrześcijaństwo, s. 69.

22 J. Ratzinger Opera Omnia, t. 11: Teologia liturgii, Lublin 2012, s. 125 (dalej: JROO, t. 11).

23 JROO, t. 11 , s. 134.

24 JROO, t. 11 , s. 92.

25 JROO, t. 11 , s. 524.

${ }^{26}$ JROO, t. 11 , s. 644 .

${ }^{27} \mathrm{JROO}$, t. 11 , s. 324.

28 JROO, t. 11, s. 615. 
się na kształt Logosu i przez wiarę stajemy się Logosem - „oto ofiara i rzeczywista chwała Boża w świecie!"29

I choć dzisiaj świat zapomina o boskich wartościach, jak: prawda, miłość, sprawiedliwość, a wśród nich nie tylko zapomina wiarę, a wręcz ją neguje, kontestuje i stara się ją uczynić bezsilną, to jednak wiara nie jest bezsilna, gdyż nie jest czymś wymyślonym przez człowieka ${ }^{30}$, nie jest produktem wspólnoty, lecz pochodzi „z góry”, od Boga, od Ducha Świętego i zawsze jest gromadzeniem, jednoczeniem, łączeniem tego, co zostało rozproszone ${ }^{31}$. Boży Duch zespala nas we wspólnym wyznawaniu wiary, która jest wiarą Kościoła, a jego teologia jest wykładnią wspólnej wiary i jej miarą ${ }^{32}$.

Trzeba zatem mieć pokorę i odwagę, a nade wszystko głęboką wiarę, by pośród wielkiego obumierania naszej wiary wokół nas, czy wręcz negacji wiary czy też negacji Boga, być transparentnym dla miłości Chrystusa w naszym życiu. Chodzi o doświadczenie wiary jako prawa akceptacji, jako zaproszenia do wspólnej radości. Wiara chrześcijańska nie jest bowiem zaciętą niekończącą się dyskusją, czy wiecznym kwestionowaniem. „Wiara w samej głębi jest akceptacją. Ona jest «tak». Ona jest radością. I pochodzi od Bożego «tak» w nas i dla nas" ${ }^{\prime \prime 3}$. Wtedy wiara rzeczywiście staje się nośną siłą człowieka, staje się po prostu miłością.

* * *

Wiara jest zatem specyficznym miejscem pojednania. Benedykt XVI uważa, że: „Wszystko rodzi się z wiary. Świat jest piękny, bo Bóg stał się człowiekiem i zamieszkał między nami, wraz z nami cierpi i żyje. Żyjąc tą radością, możemy ją nieść także innym, odrzucając zło jako 'słudzy pokoju i pojednania'"'34. Dzięki temu pojednaniu spełnia się warunek samej wiary: ona prowadzi do realnej rzeczywistości zjednoczenia osoby ludzkiej z Osobami Bożymi, do naszego przebóstwienia, do naszego wejścia w obręb życia Trójjedynego Boga. Droga ku wiecznemu życiu człowieka prowadzi przez mądrość, rozumność i jest jak najbardziej realna.

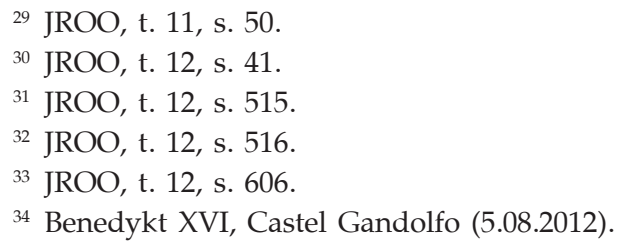


Cóż zatem powinien robić człowiek wierzący w Boga objawionego w Chrystusie? Zdaniem J. Ratzingera ma on budzić wiarę wśród ludzi, by wyswobodzić ich z ospałości i zwątpienia, by dawać im „odwagę postrzegania Boga jako rzeczywistość w tym świecie i w życiu. Tylko wtedy, gdy tak się dzieje, świat może żyć i trwać" ${ }^{\prime 35}$. Bóg nie jest więc gdzieś zamknięty $\mathrm{w}$ niebie, $\mathrm{w}$ innym i dalekim od nas świecie, lecz że On jest tu z nami, z każdym człowiekiem. Inaczej prawda o Wcieleniu Słowa Bożego byłaby zwykłym fałszem, a tak nie jest! Bóg jest z nami i pośród nas. Inaczej nasza wiara i religia byłaby bezsensowne!

Wiara w Boga Wcielonego, Ukrzyżowanego, Zmartwychwstałego i Uwielbionego w Jego Synu - ma ostatecznie prowadzić człowieka do odkrywania pełnej rzeczywistości Stwórcy i osobowego stworzenia, pełnej - bo z Bogiem Wcielonym, a nie bez Niego. Wtedy ten Wcielony Bóg da nam odwagę trzeźwości Jana Chrzciciela, czyli taką siłę, by dzięki spojrzeniu w naszym życiu doczesnym na naszego Boga - trwać niewzruszenie w cierpliwości rozumu! Rozum bowiem nie z pozycji filozofii Boga, lecz z pozycji żywej, rzeczywistej relacji z Osobą Jezus Chrystusa - nakazuje w zaufaniu do tej Osoby Pana budować nasze własne życie. Dopiero wtedy dojdziemy do dostrzeżenia pełnej rzeczywistości zarówno Boga, jak i człowieka.

Ratzinger ma zatem wielki zmysł filozoficzny. Unika fideizmu, subiektywizmu, irracjonalizmu w pojmowaniu wiary. Widzi ją jako najwyższą egzystencję umysłu, rozumu, woli, miłości i realizacji człowieka w Trójcy Świętej. I tak Benedykt XVI jest wielkim Umocnicielem wiary dla nas, dla "braci w wierze" (Łk 22,32). W zasadzie cały jego pontyfikat to wielka obrona Bóstwa Jezusa Chrystusa wobec relatywizmu i sekularyzmu świata Zachodu.

Streszczenie. Joseph Ratzinger uważa, że przyjęcie wiary przez człowieka jest dziełem współpracy rozumu z łaską Bożą. Współpracę tę uzupełnia swoją chrystologią Logosu, według której Logos nie jest tylko sensem czy myślą istniejącą w rzeczach (rozumienie greckie), lecz przez Wcielenie znajduje on swoją pełnię i staje się Logos incarnatus (rozumienie chrześcijańskie). Dlatego wiara w ten Logos daje człowiekowi nowe, wieczne życie w Bogu. Stąd wiara nie jest ślepą teorią, ani przestarzałą ideą, lecz jest „znajdowaniem drogi do mądrości, rozumności, rzeczowości." Wiara jest więc drogą do komunii człowieka z Bogiem. Jest ona kategorią osobową, a nie rzeczową. Wiara jest więc relacją osobowej miłości, gdyż Bóg jest Miłością (1 J 4,8).

\footnotetext{
${ }^{35}$ JROO, t. 12 , s. 458.
} 
Słowa kluczowe: Logos; sens; wiara; chrystologia; mądrość; rozumność; rzeczowość; Ratzinger/Benedykt XVI.

Abstract. Faith as Defined by Joseph Ratzinger - Benedict XVI. Joseph Ratzinger believes that accepting faith is an act of cooperation between human reason and God's grace. Ratzinger's concept of man-God cooperation is complemented with his Logos Christology, under which Logos is not only a sense or a thought that manifests itself in objects (Greek conception), but through Incarnation, Logos reaches its fullness and becomes Logos incarnatus (Christian conception). Hence, believing in Logos gives man new, eternal life in God. And hence, faith is not a blind theory, or an out-dated idea. Instead, it is "seeking a path towards wisdom, reason and reality." In this way, faith is a path towards man's communion with God. Faith is a personal, and not a material category. Faith is, thus, a relationship of personal love, since God is Love (1 Jn 4:8).

Keywords: Logos; sense; faith; Christology; wisdom; rationality; factuality; Ratzinger/Benedict XVI. 